\title{
Practice corner: clinical practice guidelines and handheld computers
}

\begin{abstract}
A 22 year old woman comes to your office for the first time complaining of a 1 day history of a "terrible headache." She describes a throbbing pain on the left side of her head. She works as a mail carrier, and the pain became worse this morning with walking. The patient describes accompanying anorexia, nausea, and several episodes of vomiting. She reports sensitivity to bright lights and loud sounds and tells you, "I just want to crawl into a dark corner until it goes away." She has taken ibuprofen, $400 \mathrm{mg}$ every 6 hours, without relief. The patient reports no auras, facial pain, nasal discharge, tearing, fever, neck pain or stiffness, weakness, dizziness, numbness or tingling in the extremities, or change in vision.

The patient has never had a headache like this before and has no significant medical history. She uses no medications apart from acetaminophen. Her older sister, who has had headaches of this type for several years, accompanies the patient. You decide that your patient is having a migraine and that you will probably prescribe a triptan. However, you want to know what forms are currently recommended in what doses, given the patient's severe nausea. You formulate the question: in a patient with migraine and severe nausea, what are the current best treatment options to decrease acute symptoms?
\end{abstract}

\section{Search and appraisal}

Because of time constraints, you decide to use a new application you have recently downloaded to your handheld computer. The Redi-Reference Clinical Guidelines Handbook ${ }^{\mathrm{TM}}$ is a database of summaries of clinical practice guidelines for Palm OS-based handheld computers (downloadable from shop.store.yahoo.com/pilotgearsw/redclinguide.html). The database is updated quarterly and currently includes $>30$ guidelines classified according to specialty. These include cardiology, endocrinology, infectious diseases, immunisations, neurology, psychiatry, pulmonary diseases, and other (miscellaneous). All guidelines are from specialty organisations or US federal organisations, such as the National Institutes of Health. This database functions much like the National Guideline Clearinghouse, ${ }^{1}$ a web-based, government sponsored source of guideline summaries. The guidelines are not critically appraised before being included in the database or selected according to any predefined quality criteria. It is up to the user to decide whether the guideline comes from a reliable source and to consult the full guideline, if needed, to review the process through which it was developed.

You click on the Redi-Reader icon on your handheld computer and then on the Clinical Guidelines Handbook. In the table of contents you click on "Neurology," under which there are 5 sections, including "Migraine headache." This section is divided into "Guideline source," "Background," and "Treatment." You decide that it is extremely important to know the source of the recommendations. "Guideline source" reveals that these are summaries of the US Headache Consortium Evidence-Based Guidelines for Migraine Headaches published by the American Academy of Neurology. ${ }^{2}$ You don't have time to retrieve and critically appraise the guidelines in their original form, but decide to use them. Within the guideline, you click on "Treatment," which is divided into the sections "General goals," "Non-pharmacologic," "Acute treatment," and "Preventive treatment." The priority for your patient is relieving the current headache, and you find that there are several subsections under "Acute drug therapy," including "General principles." From here you learn that the National Headache Consortium recommends migraine specific agents (serotonin receptor agonists [triptan] and ergotamine) for severe headaches or those that respond poorly to nonsteroidal anti-inflammatory drugs.

\section{Application}

You decide that the patient may benefit from treatment with a serotonin receptor agonist, given their safety and effectiveness. The guidelines recommend the intranasal or subcutaneous route of administration if the patient is nauseated and vomiting frequently. It is also recommended that an antiemetic be used to alleviate nausea. Metoclopramide is available in your office and can be administered intramuscularly. You note that you have spent just 2 minutes consulting the Guidelines Handbook on your handheld computer.

The ePocrates Drug Database Program ${ }^{\mathrm{TM}}$ is also loaded on your handheld computer. You look up sumatriptan, and since it is readily available in the pharmacy near your office, you subsequently write a prescription for two $5 \mathrm{mg}$ inhalers of sumatriptan, the second to be used if the patient's headache does not subside after the first dose. You also administer $10 \mathrm{mg}$ of metoclopramide intramuscularly. The patient begins to feel much better within an hour. You ask her to use the second dose if needed, and to return to discuss her problem further or if she has additional headaches.

\section{Evaluation}

Greater emphasis on evidence-based medicine and the impossible task of absorbing volumes of original research, improving the quality of care, and reducing unnecessary variation in care combined with a desire to control healthcare costs have all led to a staggering proliferation of practice guidelines. ${ }^{3}$ However, these guidelines have not had much impact on physician behaviour for several reasons, ${ }^{4}$ including lack of knowledge about or a negative attitude toward guidelines among physicians as well as environmental factors, such as the way guidelines are distributed.

Ideally, practice guidelines should be available at the point of care in a form that is quick and easy to digest. Handheld computers could make guidelines more practical to use. Physician use of handheld computers for many applications, including drug reference databases, is growing rapidly. $15 \%$ of physicians in the US used handheld computers in the clinical setting in 1999. By 2001, this number grew to $26 \% .{ }^{5}$ Growth is expected to accelerate as the range of medical applications for handheld computers increases. ${ }^{6}$ More evidence-based resources need to be made available for these devices. Handheld devices have received a warm reception among physicians. Hopefully the 
millions of dollars spent on developing practice guidelines will start to pay off as physicians begin to rediscover them beneath a little icon on their handheld computers.

GOUTHAM RAO, MD University of Pittsburgh Pittsburgh, Pennsyluania, USA

1 National Guideline Clearinghouse. www.guideline.gov. Accessed 19 February 2003. 2 Silberstein SD. Practice parameter: evidence-based guidelines for migraine Subcommittee of 2000;55:754-62.

Berg AO, Atkins D, Tierney W. Clinical practice guidelines in practice and education. J Gen Intern Med 1997;12 Suppl 2:S25-33.

Cabana MD, Rand CS, Powe NR, et al. Why don't physicians follow clinical practice guidelines? A framework for improvement JAMA 1999:282:1458-65.

5 Chin T. Growing medical use of handheld computers reported. Amednews.com $001 \cdot \mathrm{Oct} 8$. pick 01/tesb1008 htm \#/bar

pick - P / Infor Cleve Clin J Med 2001;68:840-2, 845-6, 848-9 passim.

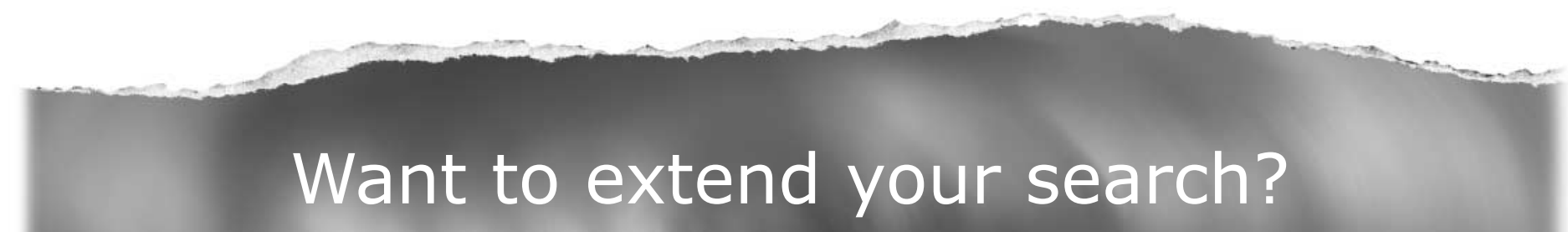
many of the more than 300 journals available for selection. You can restrict your search to specific subject areas

(eg, clinical psychiatry, basic research), or select specific journals, or search all available titles.

www.evidence-basedmedicine.com

How to cite material from Evidence-Based Medicine

Citation of material from the Notebook

Milne R, Hicks N. Evidence-based purchasing [EBM Note]. Evidence-Based Medicine 1996 May-Jun;1:101-2.

Citation for material taken from a structured abstract, written without attribution by a staff member

Antihypertensive drugs decrease mortality, coronary events, and stroke in elderly persons [abstract]. Evidence-Based Medicine 1996 May-Jun;4:105. Abstract of: Pearce KA, Furberg CD, Rushing J. Does antihypertensive treatment of the elderly prevent cardiovascular events or prolong life? A meta-analysis of hypertension treatment trials. Arch Fam Med 1995;4:943-50.

Citation for material taken from a commentary to an article

Olds D. Commentary on "Home visiting programmes reduce childhood injury." Evidence-Based Medicine 1996 May-Jun;4:112.

Comment on: Roberts I, Kramer MS, Suissa S. Does home visiting prevent childhood injury? A systematic review of randomised controlled trials. BMJ 1996;312:29-33. 
Become a Sentinel Reader for ACP Journal Club and Evidence-Based Medicine

If you are in current clinical practice in family practice or internal medicine or its subspecialties, please join us as a Sentinel Reader. As a Sentinel Reader, we'll send you "hot off the press" articles, matched to your interests, at a rate that you can control (eg, 4 articles per month).

As a Sentinel Reader:

- You will look over articles online and rate them on 2 scales

- one for relevance to your clinical practice and

- one for newsworthiness (eg, is this "news", or something you already know?).

- We'll collate your ratings with at least 2 other colleagues and use your ratings to

- choose the most pertinent articles to abstract in ACP Journal Club and Evidence-Based Medicine

- show you how other clinicians in your discipline rated the same articles

We know you'll enjoy the task: it's easy to do and informative.

If you are interested, please send us a note at PLUS@McMaster.ca

\section{Journals reviewed for this issue*}

Acta Obstet Gynecol Scand
Age Ageing
Am J Cardiol
Am J Med
Am J Obstet Gynecol
Am J Psychiatry
Am J Public Health
Am J Respir Crit Care Med
Ann Emerg Med
Ann Intern Med
Ann Surg
Arch Dis Child
Arch Gen Psychiatry
Arch Intern Med
Arch Neurol

Arch Pediatr Adolesc Med
Arch Surg
Arthritis Rheum
BJOG
BMJ
BrJ Gen Pract
BrJ Psychiatry
BrJ Surg
CMAJ
Chest
Circulation
Cochrane Library
Crit Care Med
Diabetes Care
Gastroenterology

$\begin{array}{ll}\text { Gut } & \text { J Vasc Surg } \\ \text { Heart } & \text { Lancet } \\ \text { Hypertension } & \text { Med Care } \\ \text { JAMA } & \text { Med J Aust } \\ \text { J Am Coll Cardiol } & \text { N Engl J Med } \\ \text { J Am Coll Surg } & \text { Neurology } \\ \text { J Am Geriatr Soc } & \text { Obstet Gynecol } \\ \text { J Clin Epidemiol } & \text { Pain } \\ \text { J Fam Pract } & \text { Pediatrics } \\ \text { J Gen Intern Med } & \text { Rheumatology } \\ \text { J Infect Dis } & \text { Spine } \\ \text { J Intern Med } & \text { Stroke } \\ \text { J Neurol Neurosurg Psychiatry } & \text { Surgery } \\ \text { J Pediatr } & \text { Thorax }\end{array}$

*Approximately 60 additional journals are reviewed. This list is available on request. 